\title{
China: The New Key Protagonist of International Security
}

\author{
Attila KASZNÁR ${ }^{1}$
}

"For this reason, when a ruler who has comprehended the Way (Tao) is about to employ his people, he will first bring them into harmony, and only thereafter embark on great affairs."

Wu-tzu

The People's Republic of China has become one of the leading superpowers in the World; its capabilities to protect its interests embrace not only some regional areas of the Asian continent but practically the entire World. This heading has not only positive consequences but negative effects, as well. Obviously, there are many different fields where security risks can threaten the Chinese interests. One of the most important is that parallel to the growth of China as a great power, the exposure to terrorist threats against the Chinese colonies living around the World is also growing.

Keywords: China, security policy, religion, terror, superpower, international security.

\section{Introduction}

As the People's Republic of China becomes a global power, its role as a superpower might have many peculiar features different from the development of the previous historic superpowers. This probability is high even if we consider these lines true: "we never would have thought that the rules of being a superpower would be different in case of China than in case of any other country achieving the same status.” [1: 133] At its base there is nothing but the special understanding and perceiving the World based upon Confucianism. This religiousphilosophical mentality system not only influences from time to time the Chinese domestic and foreign policy but due to its specific opportunities it can be a permanent factor exercising a basic influence with strategic consequences. Many events of the Chinese history prove that the classical political way of thinking built upon the Confucianist basis can divert the foreign policy intentions of the Asian country just to the opposite direction of the Western ideas. The accelerated process of globalization of the last decades of the $20^{\text {th }}$ century opened new opportunities for the intentions of the Chinese foreign policy driven by Chinese philosophy.

This widely spread way of thinking mentioned above which is also the motive of the specific features of the Chinese domestic and foreign policy, constituted the basis for the classical

Senior Lecturer, National University of Public Service, Institute of National Security;

e-mail: kasznar.attila@uni-nke.hu 
foreign policy with building intentions formulated in 1990 by one of the greatest Chinese politicians of the $20^{\text {th }}$ century, the mastermind of the Chinese economic miracle Deng Xiaoping, aiming the worldwide rise of the People's Republic of China. Deng said: "China must be a calm observer in the international area where its utmost priority must be to assure its position, to avoid remarkability and the leading role until its time did not come.” [2: 4] Following the words of this great politician, the People's Republic of China has made a really "big jump" in the last three decades. Its result is that "China has gained its proper place in the world, drawing on its generally peaceful international relations to provide the context for its booming trade. The country which once suffered under the unequal treaties imposed by foreign powers now helps to fund the US federal deficit.” [3: 678-679] It seems that the actual leaders in Beijing consider that it is time for the Chinese state to implement strongly than ever before its interests in the international area thus playing in the future the role of a real global superpower. This is also reflected in theideas expressed by the President of the People's Republic of China, Xi Jinping, on the $19^{\text {th }}$ Congress of the Communist Party of China held between 18 and 24 October 2017. He made it absolutely clear that the country must undertake a leading role in the World. At the same time, this does not mean that the People's Republic of China would give up its refined international policy built upon the traditions of the Confucianist philosophy, carried out by carefully developed and from a strategic point of view consisting of a complicated series of rational and well-conceived small steps. What certainly can be expected is the rise of new strategic points.

The fact that Xi declares the status of a global superpower of the People's Republic of China raises many actual social, economic, cultural and political questions. Obviously, the majority of researchers pay attention to the economic side because-as it was clear according to Deng Xiaoping's words - the People's Republic of China had been concealing its military, strategic, law enforcement and other capabilities related to these areas up to the latest years. At the same time, the People's Republic of China's economic leading role is imminent and is undisputable even for outsiders. The current situation needs some explication because "there are discussions about how the power of China growing with amazing speed during the years 2000 can be integrated into the global structure of power. It becomes more and more clear that China is the most important challenge of the American hegemony." [4: 50] With other words: the security policy of the Chinese leadership has many segments but the present study focuses mainly on a narrow slice of the security policy, i.e. being a superpower and the terrorist threat as a consequence of it.

\section{China as a Superpower}

In case of China, historical traditions determine the fact of being a superpower because in historiography China can mostly be referred to as an empire. In this case we can accept the words of the famous British historian, Stephen Howe about empires. He wrote: "it is a complex political entity with huge extension, embracing many people or nations, emerging as a consequence of conquest, composed of a dominant center and subordinated peripheries often far from the center." [5: 40] It is a good question to what extent the actual China fits this expression acceptable in a historical context. The answer is unambiguous, inasmuch as the People's Republic of China "due to its extension, economic, political, military power 
and cultural influence plays a leading role in international life” [6: 8] and meets more and more the basic requirements toward being a superpower. Observing the events, the People's Republic of China has achieved today the aims set by Deng Xiaoping in 1980, except the criteria of democracy: " The goal of the building work for the socialist modernization is to achieve the level of the developed capitalist countries, to create a more clear and real democracy of higher standards, to educate and train more and better specialists than in these countries.” [7: 110]

If we analyse the characteristics of the worldwide economic control of the People's Republic of China we can see that this country has chosen an extremely particular way not only in its internal policy but in its international expansion, too. We should not forget that the motive at the background is the same as in case of other countries: the need of satisfaction of demands of raw materials, acquiring new markets. Based upon the analysis of the on-going processes the further mid-term or even long-term expansion of the People's Republic of China can be forecasted without a risk. The opportunities of the exploitation of raw materials have been significantly changed during the last decades, and as a result of these transformations the resources has become Chinese property. ${ }^{3}$ This fact basically changes the correlation of powers emerged after WW2, and also questions the future competitive potential of the former great powers - mostly the leading countries of Western culture. The actual correlation of powers and their development tendencies-sometimes their retrogradation - show that the United States is the only factor which can be a potential counterweight against the control of China holding in its hand the growing slice of the high-tech production of the World. The emerged situation visualizes the appearance of a new bi-polar world order where the advancing of the People's Republic of China and the regression of the United States is expected - as the consequence of the correlations described above.

In this newly forming system quite a lot of new moments are also to be expected. Their character will be determined by applying the Confucianist ideology to use the capitalist methods for the global positioning of the People's Republic of China implementing Chinese socialism. Notwithstanding, "a natural feature of high-tech capitalism is the permanently increasing productivity and the growing intensity of the working rhythm, and at the same time, high-tech capitalism has made possible to achieve a higher living standard and better nutrition and higher consumption, as well.” [8: 16]

If we agree with the idea of the world-wide known philosopher of our era Slavoj Žižek, we can come to the conclusion that the global control and the economic development transform the demands of the Chinese internal market so much-increasing its purchasing capacities i.e. the internal consumption - that as a consequence the satisfaction of the demands of goods can shrink in other areas of the World. Due to the appearance of deficit economies which emerged as a consequence of the deficit of goods in different regions combined with the effects of climate change can bring a situation when tens of millions of people

2 Naturally, the different concepts of democracy can generate many discussions because beside the Western concept of democracy many other ideas can be the subject of political and professional discussions.

3 As an especially interesting point, it worth mentioning that one of the strategic ideas of Deng Xiaoping was that the People's Republic of China should focus on obtaining access to the resources of rare metals. The result today is that $90 \%$ of the global resources are in Beijing's hand. This fact is a clear national security risk for the majority of the countries with developed electronic and military industry since rare metals are indispensable for these fields of industry. 
will be obliged to leave their previous living areas exposing the whole developed world to the security and safety risks caused by a contemporary migration of people. In another way: if we analyse the connections of the facts we can arrive at the conclusion that one of the indicators of the contemporary migration processes is the People's Republic of China becoming a superpower. ${ }^{4}$

\section{The Special Background of China as a Superpower}

As stated previously, today, the status of superpower of the People's Republic of China has become indisputable together with its special components. In addition to the well-known superpower factors, in case of China it is important to mention the specific religiousphilosophical background which-due to the superpower achievement of the Far Eastern country-has become a dimension in the general security policy. The fact that in the focus of the Chinese socio-philosophical thought is the family and not the individual offers a special background which makes the actuations of the Chinese not only un-understandable and unforeseeable for societies based on the philosophy of individualism but it also makes difficult the cooperation in the international political field. The states constituting the current international system mostly observe the positioning of the People's Republic of China which shakes at the base the previous system of frames and creates new dimensions possibly provoking new security risks, as well. Without any doubt, the most notable moment of this new security environment is the world-wide Chinese economic control. In case of China, the economic expansion is accompanied by the rise of Chinese migrant communities or colonies which in their turn create a special fundament for the further global Chinese positioning and control. ${ }^{5}$

The parallel processes - the People's Republic of China becoming a new superpower and the appearance of the new colonies world-wide-mean new security challenges for Beijing.

The fact that the People's Republic of China and the Chinese are present everywhere in the World may become a source of numerous conflicts even if we admit that the Chinese immigrants can integrate in the hosting society practically with fewer conflicts than any other migrant communities. This can be seemingly confirmed by the words of Samuel P. Huntington who said the Chinese nationals "almost in the majority of the South-Asian countries are the economically dominant minority. They have assimilated in the Buddhist Thailand and the Catholic society of the Philippines and there are only rare cases of violent anti-Chinese acts from the majoritarian groups.” [9: 451]

We can state that the Confucianist thought and the Chinese immigrant communities' network following these ideas give a special background for the People's Republic

4 This is not a critical remark on the Government of Beijing. This is just a fact which can fit any state which achieved a similar level of development.

5 The emigrants of China have a compact system of religious-philosophical values which is the basis of their behaviour and activities in their new circumstances and guides the relations to each other and their motherland - including the material, moral and political support of their relatives and homeland. One of the key moments of the People's Republic of China becoming a superpower is the formation of a network of the religious-philosophical system through the Chinese migrant communities which is a significant advantage in building the Chinese system of power. About the importance of the role the Chinese communities play in becoming a superpower read more in source [17]. 
of China to become a superpower, although they represent a number of security risks both for the hosting countries and Beijing. Having a huge number of Chinese nationals beyond the borders creates a special risk for Beijing because by attacking these groups, the People's Republic of China can be blackmailed or forced to take undesired measures.

\section{The Appearance of Terrorist Threats Concerning China as a Superpower}

The experience related to security policy shows that the primary security challenge for the centres of power is not the classic threat any more but the asymmetric warfare, terrorism that is "basically a political phenomenon with structural and psychologic factors.” [10: 5] István Gál’s words confirm what previously has already been set out that China becoming a superpower-especially the fact that this goes on in the international political space-makes the People's Republic of China a new target for global terrorism. Parallel to the growth of the activity against China and the Chinese nationals on behalf of the terrorists, the attitude of Beijing toward terrorism will change "the majority of steps of fighting terrorism related to its persecution more and more depends on the level of the terrorist threat of the given country and society.” [11: 46] It seems the actions against terrorism undertaken by the People's Republic of China in the future will be concentrated less and less on the territory of the country and will acquire a more international character.

At this point it is important to determine what are the specific features of the terrorist threats against the People's Republic of China as a superpower, what kind of terrorist challenges China has to face in the near future. The terrorist challenges against the People's Republic of China can be split into four big groups:
a) internal terrorism;
b) terrorism from abroad;
c) terrorist attacks against Chinese interests;
d) terrorist attacks against the Chinese colonies.

Now I'll give an explanation to every kind of possible threat:

a) Internal terrorism in the People's Republic of China has a long past and it can be linked mostly to the Uyghur national group. The separatist movements of the Uyghurs have exercised traditionally outstanding influence on the security status of the Western side of China, especially in Xinjiang, the Uyghur Autonomous Region. The most significant separatist group, the Turkistan Islamic Party (TIP) aka the East Turkistan Islamic Movement (ETIM) has been formed up to the end of the $20^{\text {th }}$ century. They are responsible for the majority of attacks perpetrated on the territory of China. [12] The radical Islam organization has the intention of creating a giant Islamic state from China to Turkey, therefore they maintain close relations with the communities with similar ideology in the region and with the Islamic State, as well. The fact that the ETIM has become an active member of the international terrorist network visualizes the growth of the internal terrorist attacks in the People's Republic of China. 
b) As a superpower, the People's Republic of China has to face in the future the fact that the international terrorist communities of foreign origin will more frequently consider Beijing their enemy and the Chinese state their primary target. These terrorist groups which "during the perpetration of their operations cross one or several state borders” [13: 68] can find several opportunities to penetrate into China’s territory and perpetrate attacks there. One of the main opportunities to infiltrate is that the member organizations of global terrorist networks, such as the Islamic State, after losing their main operational scenes can transform into an unconsolidated, often cell-like operational structure. In this form the members with different nationalities can transfer their operational scenes to the best-known areas i.e. to their homeland where they can also become perpetrators and can facilitate the penetration of the infiltration of terrorists of other nationalities and their illegal activities. Another point of the infiltration of terrorists into the People's Republic of China has an implication of migration; the further development of China generates demand of labour force what provokes economic migration. It is also expected that the illegal immigration to the People's Republic of China will become an important problem soon. Its signs are already seen: the number of the black workers coming from SouthEast Asia is significantly growing. This massive influx can serve as an excellent cover for terrorist communities.

c) The international role of the People's Republic of China is increasing thus the country appears in the focus of attention of terrorist communities. Parallel to this the number of attacks against Chinese interests-factories, mines, installations, workshops, and even against tourists coming from China ${ }^{6}$ — can become more frequent. This widerange target is only a part of the targets of the terrorist acts of previous decades. The exposure of Western citizens to terror on the primary operational scenes of the potentially dangerous terrorist organizations is doubtless. There have been a huge number of attacks perpetrated against Western citizens - tourists or workerson the territory of the primary operational scenes of terrorist organizations. It is also probable that the Chinese coming from China will be exposed to this kind of threat in the future.

d) As told previously, the Chinese colonies bring significant advantages to Beijing, building its status as superpower in the process of peaceful multidimensional control but nevertheless, they are exposed to different threats and dangers. One of the threats is terrorism which can target the Chinese communities living in many points of the World. Their protection against terrorism has difficulties unknown at this level; due to the difference from other superpowers, an appropriate method to combat had not yet been elaborated.

It seems that due to its status of superpower, the People's Republic of China and its complex region can be exposed to different forms of terror threat coming from different directions. Handling these problems needs significant forces.

6 About tourists coming from a given country and becoming targets see in detail [18]. 


\section{Conclusions}

There is an ever recurring question that if globalization transforms the World, why would China be the only exception? Well, it is for sure that the global processes which have helped the People's Republic of China to become a leading country in the World will influence the Chinese society, at the same time we should not forget the eternal words of Lin Yutang concerning the Chinese: "The more we change the more we remain who we have been.” [14: 354] These words disclose that the more active role the Chinese will play in the international security policy processes their participation will follow their own way composed meticulously and intentionally of small and well-elaborated steps. It will give them time to learn the challenges and to elaborate the most efficient steps from the position of a global power since "the preparation and training are important and determining factors because this is one of the ways of successful warfare, including the economy of human lives." [15: 13]

Parallel to the economic prominence of the People's Republic of China embracing all continents, the global positioning of the appearance of migrant communities with Chinese religious-philosophical conscience is growing. The Chinese immigrants constitute the basis of the contemporary Chinese superpower-policy since they can make the hosting country economically dependent and can contribute to the process of the peaceful conquest called cultural osmosis by Henry Kissinger. [16: 550]

It can also be forecasted that responding to the global control of Beijing and as the People's Republic of China becomes a superpower, the actions of global and local terrorist organizations against this country will become more active. Of course, as a reaction to the increasing terrorist activity Beijing will be forced to take more active than ever measures countering terrorism. This process is a self-generating one: the more significant military and law enforcement measures can lead to more radical actions on behalf of the terrorist organizations and their activists. After the elimination of a terrorist organization newer terrorist communities can and will emerge much more bloodthirstily than before which will mean a new challenge for the Beijing Government. After a short analysis of these reflections one can easily come to the conclusion that the People's Republic of China will become an outstanding role-player of the international struggle countering terrorism.

\section{References}

[1] HÁDA B.: Útban egy nemzeti álom felé? - Kína 2015. évi katonai stratégiája. Nemzet és Biztonság, 3 (2015), 125-133.

[2] MATURA T.: A Kínai Kommunista Párt 19. kongresszusa és egy új korszak hajnala. SVKK Elemzések, 29 (2017), 1-8.

[3] FENBY, J.: The Penguin History of Modern China: The Fall and Rise of a Great Power, 1850-2008. London: Penguin Books, 2008.

[4] DANNREUTHER, R.: Nemzetközi biztonság. Budapest: Antall József Tudásközpont, 2016.

[5] HOWE, S.: Birodalmak. Budapest: Magyar Világ Kiadó, 2004.

[6] SZUNOMÁR Á.: Kínai nagyhatalmiság. http://phd.lib.uni-corvinus. hu/680/1/Szunomar_ Agnes.pdf. 2012. (Downloaded: 20.01.2018) 
A. KASZNÁR: China: The New Key Protagonist of International Security

[7] DENG, X.: A párt- és az államvezetés rendszerének reformjáról. Peking: Népi Kiadó, 1983.

[8] ŽIŽEK, S.: Zür a paradicsomban. Budapest: Európa Könyvkiadó, 2016.

[9] HUNTINGTON, S. P.: A civilizációk összecsapása és a világrend átalakulása. Budapest: Európa Kiadó, 2004.

[10] GÁL I. L.: Új biztonságpolitikai kihívás a XXI. században: a terrorizmus finanszírozása. Szakmai Szemle, 1 (2012), 5-15.

[11] TÁLAS P.: A terrorveszélyhelyzet-diskurzus margójára. Nemzet és Biztonság, 1 (2016), 40-47.

[12] XU, B., FLETCHER, H, BAJORIA, J.: The East Turkestan Islamic Movement (ETIM). www.cfr.org/backgrounder/east-turkestan-islamic-movement-etim (Downloaded: 22.01.2018)

[13] MARAS, M-H.: A terrorizmus elmélete és gyakorlata. Budapest: Antall József Tudásközpont, 2016.

[14] LIN, Y.: Mi kínaiak. Budapest: Révai Kiadás, 1943.

[15] PADÁNYI J.: Egy kínai hadtudós gondolatai. Szun-Ce: A hadviselés törvényei. In. GŐCZE I. (szerk.): Állam és katona. Budapest: Dialóg Campus Kiadó, 2017. 7-16.

[16] KISSINGER, H.: Kínáról. Budapest: Antall József Tudásközpont, 2014.

[17] KASZNÁR A.: National security aspects of the Chinese headway. Nemzetbiztonsági Szemle, Special Issue (2017), 76-81.

[18] BÁCS Z. Gy.: Turizmus és biztonság: turizmus a terrorizmus árnyékában. In: GONDA T. (szerk.): A Kárpát-medence turizmusának és vidékfejlesztésének aktuális kérdései. Tanulmányok a turizmus és a vidékfejlesztés témaköréből. Szekszárd: PTE, Kultúratudományi, Pedagógusképző és Vidékfejlesztési Kar, 2016. 150-160. 